\section{Sustainability requires broad cultural effort}

In a previous letter (Amer. J. Alt. Agric. 4:1, 43, 1989) I reviewed some concerns regarding the present state of the public and scientific discussion of agricultural sustainability (or rather agrosustainability). In the intervening months I have continued to notice the myopia of technical investigators in this field. Sustainability cannot be achieved through scientific efforts alone; it must be built through broad cultural efforts. Sustainability requires that each system is uniquely coevolved with highly aware and evenly equanimitable stewards. That is, sustainable systems arise in conjunction with the cultural evolution of the human community.

Another idea that I call "the ecological uncertainty principle" is instrumentally important to attaining sustainability. In short, no measurement of ecosystems can be made without altering them. As well, the management of ecosystems always involves unintended, and frequently harmful, though occasionally helpful, influences on those functioning systems. So, in managing ecological systems (the role of agriculture), we must be ever wary and ever flexible, ready to adjust to the unexpected and the unforeseen. This means managers have to learn to "fly by the seat of their pants," not "by instruments." Those scientists and technicians who think they can create agrosustainable systems by some kind of interchangeableparts, mass-production approach will probably be sorely disappointed.

I believe that the road to agrosustainability (or, for that matter, cultural sustainability) will be built and followed well by people who create accurate "inner ecologies," that is, ecologies of mind (Gregory Bateson, Steps to an Ecology of Mind, 1978) and who adopt as their guidelines not sci- entific paradigms but rather artistic and spiritual metaphors of the world. I believe this because the efforts of agriculturalists and their societies since the advent of the Industrial Revolution and even before have largely resulted in destructive and self-limiting methodologies. During the latter ages of human history, the faiths in science and technology have allowed purely economic and anthropocentric views to predominate. Those views reinforced the biases that convinced many people that natural resources and natural processes were limitless and invulnerable. Hopefully, most (or at least enough) of us have now begun to see these as fallacies and will begin to learn to know better.

Rick Williams

Assistant Professor of

Agriculture/Biology

Ferrum College

Ferrum, VA 24088

\section{FmHA "buy back" loans linked to high-input farming}

Some farmers with productive lands make a good living through effective management, high output of crops with a favorable market, and federal subsidies. But some who borrow to purchase land at a price exceeding its value for agriculture cannot repay their loans. So it was at a neighboring farm, recently auctioned. The "owner" had 350 acres, about one-third of it bottomland, loans on land and equipment of over $\$ 400,000$, and interest payments of about $\$ 25,000$ per year. FmHA bought the farm for $\$ 130,000$, or $\$ 371.43 /$ acre. This is the first step in a process that favors high-input agriculture.

The 1987 Agricultural Farm and Credit Bill provides that a farm foreclosed and purchased by FmHA must be offered first to the former owner as "lease back" or "buy back." If buy

\section{LETTERS TO THE EDITOR INVITED}

The AJAA welcomes letters, short or long, commenting on articles in this journal or sharing ideas likely to be of interest to other AJAA readers. Since our space is limited, we do reserve the right not to publish all letters or, at times, to publish only excerpts from them. To take part in this exchange of ideas, write to: Editor, AJAA, 9200 Edmonston Road, Suite 117, Greenbelt, MD 20770.

back, the purchase price would be the capitalized value as a farm, based on a return of $81 / 2$ percent on the investment - $\$ 130,000$ is near the price that FmHA would calculate currently in the case of the farm near mine. If the former owner doesn't have money, FmHA may provide a credit (loan). If offered by FmHA and accepted by the former owner, he is then obligated to pay interest at $81 / 2$ percent and to pay back the principal over a term that can be as long as 40 years. These payments mean that there can be net income only when the land under discussion returns more than about $\$ 15,000$ per year ( $\$ 43$ per acre per year). Consider the choices involved in managing the land to insure this income.

Low-intensity usage of rangeland involves cows that graze native grasses in summer and some tame pasture plus a supplement in winter. The cows produce calves for sale each year. If spouse and children share the work of watching and tending bovines, there could be time for garden and orchard with additional income, and the husband and/or wife can work off the farm as well. Such an operation on a small farm 
involves little money at risk and conserves soil and water, but it is apt to produce only about $\$ 25$ per acre above inputs each year on the farm under discussion. That alone cannot pay for the farm and is not a basis for FmHA transferring the property to a new or former owner.

Large-input agriculture, by contrast, puts more money at risk, implies substantial use of chemicals, produces larger outputs in rough proportion to inputs, and holds a prospect of greater gains (and also greater losses).
FmHA will estimate the income that can be gained the high-input way and the corresponding farm value. By this path, our government encourages some farmers both to stay on the land and to practice high-input agriculture. There are many implications of this policy for the structure of agriculture, agricultural production, farm implement and chemical manufacture, and the nature and welfare of rural America.

Edwin Kessler

Rt. 2, Box 137

Purcell, OK 73080

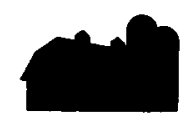

\section{RESOURCES}

Agricultural and Food Policy Decisions, Report No. 89-4 from the Economics Department of South Dakota State University, concludes that nearly 70 percent of South Dakota farmers and ranchers surveyed in 1989 think that federal farm policies should encourage reduced use of synthetic chemical fertilizers and pesticides. The same percentage also think that soil conservation and water quality compliance should be a condition for receiving farm program benefits and that the government should regulate certain farming practices and land uses to reduce water pollution. For information, contact the Economics Department, South Dakota State University, Box 504A, Brookings, SD 57007.

Educational and Training Opportunities in Low-Input/Sustainable Agriculture: A Directory, from the National Agricultural Library's Alternative Farming Systems Information Center, lists over 100 groups, colleges, and agencies nationwide who provide such opportunities. Request copies from the USDA, National Agricultural Library, AFSIC, Room 111, 10301 Baltimore Boulevard, Beltsville, MD 20705.
The New Organic Grower, by Eliot Coleman, is a manual of tools and techniques for the home and market gardener. Coleman is nationally recognized for his work with model small-scale farms in Vermont and Maine. The 320-page book covers everything from land purchase to management and harvest of crops. It is $\$ 19.95$ (plus $\$ 2.50$ postage/handling) from Chelsea Green Publishing Company. Send orders to A.I.D.C., 64 Depot Road, Colchester, VT 05446.

Farmer-to-Farmer Directory, from the Sustainable Farming Association of Southeast Minnesota, lists 78 farmers willing to share their experience in using alternative farming techniques. The group ranges from conventional farmers just beginning the reduction of chemical fertilizers and pesticides to those using no synthetic chemicals in production. The directory is offered as a benefit of membership at $\$ 10 /$ year. Contact the SFA, P.O. Box 53, 180 East Main Street, Lewiston, MN 55952, (507) 523-3366.

Farmland: A Community Issue, from Concern, Inc., is a citizens guide to farming practices and the ways in which sustainable agriculture can ben- efit everyone. An action guide, reference to pertinent legislation and examples of successful state and local initiatives are given. The booklet is $\$ 3$ from Concern, Inc., 1794 Columbia Road, NW, Washington, DC 20009.

The Global Pesticide Monitor is a new newsletter of the Pesticide Action Network's North American Regional Center. The first issue carries a lead story on the current status of effects from the Bhopal, India, explosion that sent clouds of lethal gases through poor neighborhoods. It also covers export of pesticides, the World Bank pesticide policies, and other news. Subscription rates are $\$ 25$ for individuals and nonprofits, $\$ 50$ for government or corporate institutions. Contact the PAN NA RC, P.O. Box 610, San Francisco, CA 94101.

Earth Ethics, a 16-page quarterly journal on "evolving values for an Earth community" provides short excerpts, book reviews, and current action in environmental ethics. It is edited by Sara Ebenreck, contributing editor to the $A J A A$, and is $\$ 10 /$ year from the Public Resource Foundation, 1815 H Street, NW, Suite 600, Washington, DC 20006. 